\title{
THESIS COMPLETION ANALYSIS USING OPTIMISTIC BIAS POSSIBILITY
}

\author{
Bagus Wahyu Utomo \\ Departemen Teknik Industri \\ Sekolah Tinggi Teknologi Adisutjipto \\ Jalan Janti Komplek Lanud Adisutjipto, Blok R, Yogyakarta \\ Email : baguswahyu@stta.ac.id
}

\begin{abstract}
Thesis is a condition that must be fulfilled by prospective graduates to be able to get a bachelor's degree. This study uses optimistic bias because in general humans experience overestimation (optimistic bias) on things that are considered as positive events, but underestimate (pessimistic biases) on negative events. This study uses the completion time of the Final Project Report as a case study. The results of this study are that there are systematic errors / biases in the accuracy data at the estimated time of completion of the final project. Accuracy time occurs Optimistic bias because the estimated value tends to be smaller when compared with the actual time value. Statistically it can be concluded that there is no difference in the accuracy of the estimated data completion of final assignments between male and female students.
\end{abstract}

Keyword: Project Time Estimation, Optimistic bias, Thesis

\section{Pendahuluan}

Secara umum, seorang mahasiswa/i yang berada pada tingkat akhir diharuskan untuk mengaplikasikan seluruh ilmu yang telah dipelajarinya, sebagai bahan uji kemampuan apakah dia kelak sanggup untuk menghadapi dunia kerja yang berat [1].

Skripsi nenjadi satu syarat yang harus dipenuhi oleh calon sarjana untuk bisa mendapatkan gelar sarjana. Oleh karena itu, mahasiswa harus menyusun target-target tertentu untuk bisa mempertanggungjawabkan tugas akhirnya tersebut di hadapan dosen pembimbing dan dosen penguji [2].

Skripsi memiliki waktu mulai dan akhir, maka skripsi dapat dikategorikan sebagai proyek berskala kecil. Proyek memiliki risiko yang dapat membuat realisasi proyek tidak sesuai dengan waktu, kualitas, dan biaya yang telah di tentukan dalam perencanaan sebelumnya. Salah satu pemicu munculnya risiko adalah minimnya data historis proyek. Karenanya, untuk mengestimasi waktu proyek digunakan pendekatan subjective expert judgment / expert opinion yang merupakan salah satu aspek kognitif dalam pengambilan keputusan / estimasi. Estimator berpengalaman pada proyek cenderung untuk underestimate atau mengalami pesimistic bias ketika menilai kapan proyek akan selesai atau berapa banyak biaya yang dikeluarkan untuk proyek tersebut. Jika estimasi lebih baik dari aktual dinamakan optimistic bias, jika aktual lebih baik dari estimasi maka dinamakan pesimistic bias [3].

Penelitian ini menggunakan optimistic bias karena secara umum manusia mengalami overestimate (optimistic bias) pada hal-hal yang dianggap sebagai positive event, namun mengalami underestimate (pesimistic bias) pada negative event.

Penelitian ini menggunakan waktu penyelesaian Laporan Tugas Akhir sebagai studi kasus. Pembuatan Tugas Akhir merupakan salah satu kegiatan yang masuk kategori proyek karena memiliki durasi tertentu, bersifat unik, dan dikerjakan oleh lebih dari satu disiplin 
ilmu. Salah satu pemicu munculnya risiko kesalahan estimasi waktu penyelesaian skripsi adalah karena mahasiswa kewalahan saat membuat skripsi. Kewalahan tersebut bisa muncul karena berbagai alasan. Bisa karena mahasiswa tidak memahami apa yang ditulis dan dibahasnya dalam skripsi tersebut, bisa juga mahasiswa tersebut kewalahan karena sulit membahasakan apa yang ada di dalam pikirannya ke dalam sebuah tulisan.

Tujuan yang ingin dicapai dalam penelitian ini adalah mengidentifikasi ada atau tidaknya pengaruh optimistic biases terhadap estimasi penyelesaian Tugas Akhir.

\section{Metodologi Penelitian}

Sebuah proyek adalah usaha sementara untuk membuat produk, jasa, dan hasil yang unik [4]. Proyek-proyek penelitian biasanya memiliki waktu jangka panjang di mana kualitas diutamakan dari waktu ke waktu[5]. Ini adalah proses intelektual dimana scope mungkin tidak didefinisikan sama sekali diawal. Judgment adalah kemampuan manusia untuk mengambil kesimpulan, mengestimasi, dan memprediksi karakter dari kejadian yang tidak diketahui [6]. Semua judgment dibuat dengan pengetahuan yang tidak sempurna, dengan demikian tidak ada estimasi yang benar-benar akurat dan prediksi yang sempurna. Hal ini disebabkan karena ketidakpastian akan kejadian dimasa yang akan datang dan juga adanya pengaruh dari internal dan eksternal yang dialami oleh seorang expert ketika akan memberikan judgment pada sebuah prediksi. Kesalahan pada keputusan oleh expert saat memberikan judgment dan dibandingkan dengan hasil yang diperoleh adalah judgmental biases [7].

Penelitian ini melibatkan responden yang berasal dari mahasiswa salah satu perguruan tinggi di Yogyakarta. Responden yang dipilih adalah mahasiswa yang akan membuat dan menyelesaikan Tugas Akhir dengan target responden sekitar 30 orang. Peralatan yang digunakan dalam penelitian ini antara lain Software Microsoft Excel, Laptop/ computer, Worksheet dan alat tulis, dan Software SPSS. Penelitian ini dilakukan di salah satu perguruan tinggi di Yogyakarta.

Variabel bebas (independent variable) pada penelitian ini adalah responden mahasiswa dan estimasi waktu penyelesaian Tugas Akhir, variabel terikat (dependent variable) adalah Optimistic bias. Pola hubungan variabel bebas dengan variabel terikat di tunjukan pada Gambar 1

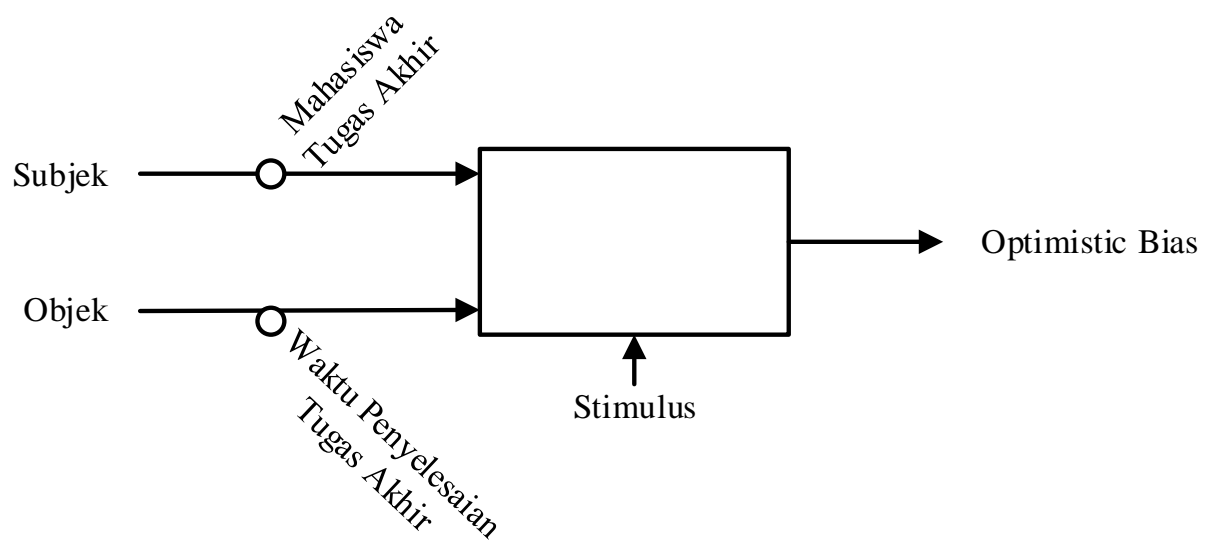

Gambar 1. Pola Hubungan Variabel Bebas dan Variabel Terikat

Urutan pengerjaan penelitian ini ditunjukan pada Gambar 2. 

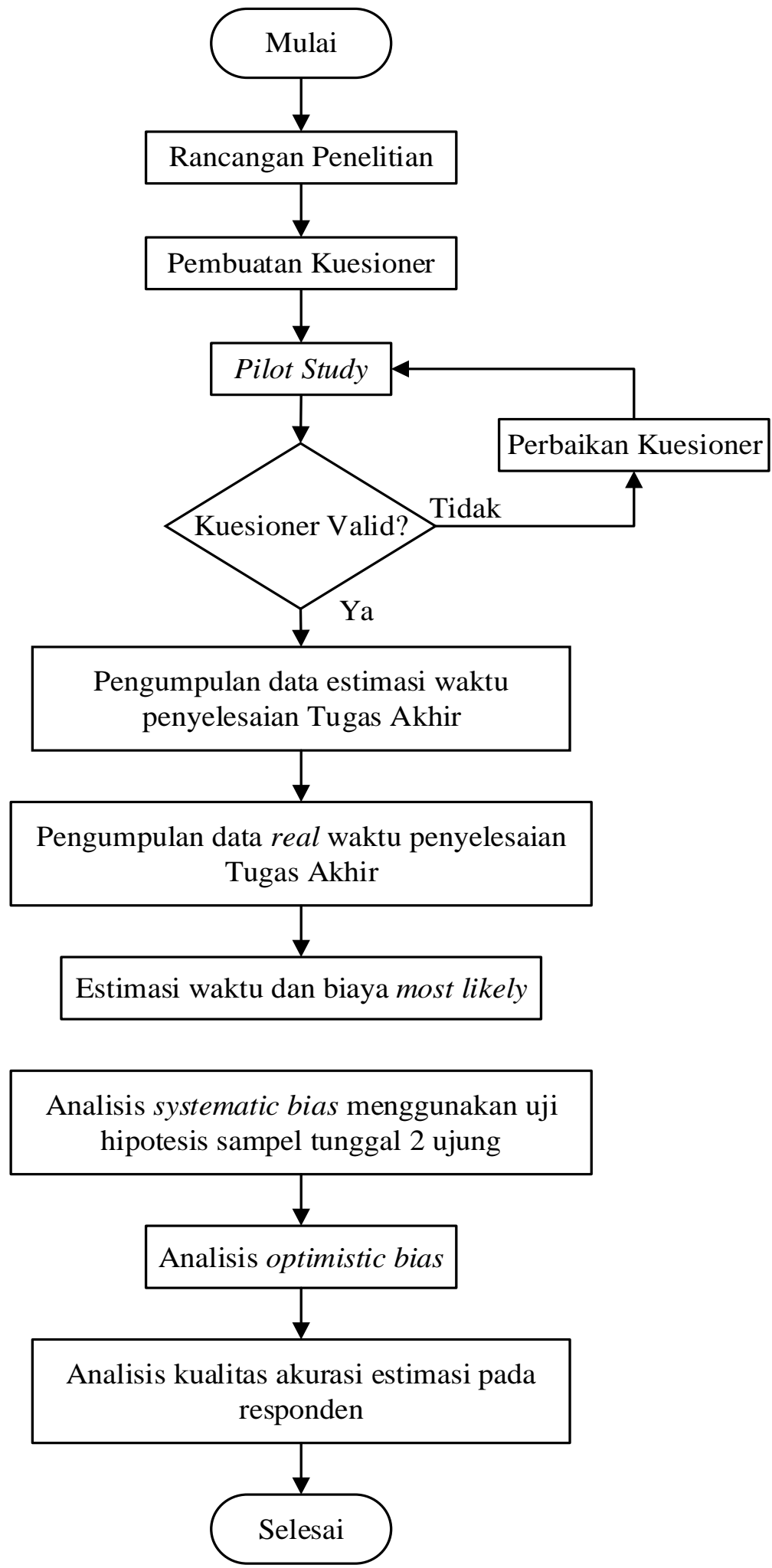

Gambar 2. Diagram Alir Penelitian

Penelitian dilakukan untuk mendapatkan estimasi responden dalam menentukan estimasi waktu penyelesaian tugas akhir mahasiswa. Objek penelitian yang yang menjadi kasus adalah Tugas Akhir yang di kerjakan oleh mahasiswa salah satu perguruan tinggi di Yogyakrata. Responden penelitian adalah mahasiswa tingkat akhir yang akan dan sedang melaksanakan Tugas Akhir. 
Kuesioner digunakan sebagai task kepada responden dalam menjawab pertanyaanpertanyaan (item) yang terkait dengan estimasi waktu pengerjaan Tugas Akhir. Pilot study dilakukan untuk mengevaluasi apakah kuesioner sebagai instrumen penelitian sudah sesuai dengan tujuan penelitian. Pilot study dilakukan kepada lima orang expert proyek Tugas Akhir yang tidak termasuk dalam responden penelitian. Evaluasi kuesioner menggunakan content validity dan face validity Content validity digunakan untuk mengevaluasi apakah item-item pertanyaan pada kuesioner sudah dapat mengukur semua aspek yang dibutuhkan dalam penelitian ini. Face validity digunakan untuk mengevaluasi apakah instruksi dan item-item pertanyaan sudah jelas, tidak ambigu, dan benar secara logika.

Pengumpulan data realisasi proyek diambil dari perguruan tinggi yang terdiri dari Data waktu riil penyelesaian tugas akhir pada tahun ajaran 2018/2019. data mahasiswa yang akan dan sedang menyelesaikan tugas akhir, data bidang minat yang dipilih untuk tema tugas akhir.

Pengumpulan data kuesioner untuk faktor Optimistic Bias adalah sebagai berikut data riil aktual durasi pengerjaan tugas akhir disimpan oleh peneliti, data estimasi waktu most likely setiap responden diambil dari nilai tengah antara durasi waktu optimistic dan durasi waktu pesimistic. Data estimasi biaya most likely setiap responden diambil dari nilai tengah antara biaya optimistic dan biaya pessimistic, hasil estimasi waktu most likely dan biaya most likely tugas akhir oleh responden dibandingkan dengan waktu dan biaya realisasi aktual penyelesaian tugas akhir.

Untuk menganalisis kemungkinan optimistic bias yang terjadi, masing-masing set data estimasi waktu dan biaya most likely tersebut dikurangi dengan data waktu dan biaya aktual pengerjaan Tugas Akhir, sehingga menghasilkan akurasi dari Tugas Akhir. Rata-rata akurasi bernilai positif atau negatif merupakan petunjuk apakah estimasi yang dihasilkan mengalami optimistic bias atau tidak.

\section{Hasil dan Pembahasan}

Responden pada penelitian ini adalah mahasiswa di beberapa perguruan tinggi di provinsi D.I. Yogyakarta yang sedang menyelesaikan tugas akhir nya. Responden terdiri atas 17 orang mahasiswa putra dan 13 orang mahasiswa putri. Mahasiswa tersebut berasal dari berbagai jurusan atau program studi.

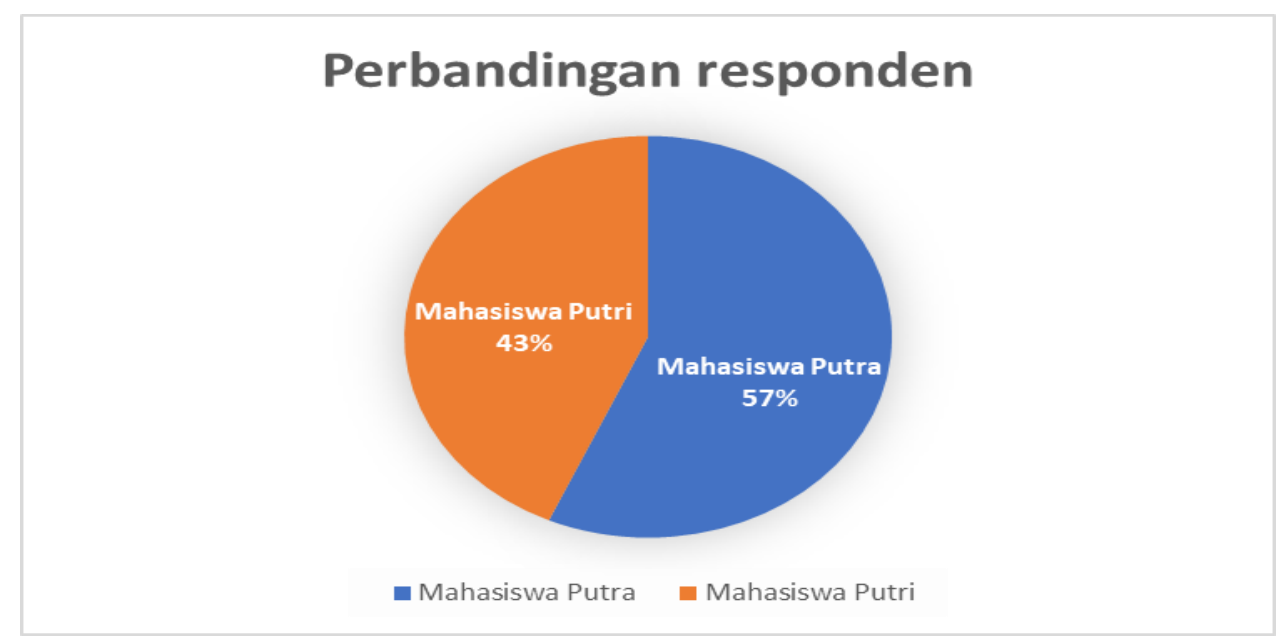

Gambar 3. Perbandingan Responden 
Berdasarkan gambar 3 ditunjukan perbandingan responden pada peneltian ini yaitu $43 \%$ untuk mahasiswa putri dan $57 \%$ untuk mahasiswa putra.

\subsection{Analisis Optimistic Bias}

Analisis optimistic bias dilakukan untuk melihat apakah terjadi kesalahan yang sistematis (bias) pada pengambilan keputusan pada estimasi waktu pengerjaan tugas akhir.

Untuk menganalisis kemungkinan optimistic bias yang terjadi, data estimasi waktu tersebut dikurangi dengan data waktu aktual pengerjaan tugas akhir, sehingga menghasilkan tingkat akurasi dari estimasi penyelesaian tugas akhir. Secara matematis dapat dituliskan sebagai berikut:

Akurasi $(\Delta)$ estimasi waktu = waktu estimasi - waktu aktual

Analisis dilakukan dengan menguji secara statistik data tersebut dengan uji hipotesis mean sampel tunggal kemudian dilanjutkan dengan uji $z$ saling bebas untuk mengetahui kemungkinan adanya systematic bias dalam melakukan estimasi penyelesaian tugas akhir. Banyak jenis pengambilan keputusan dari masalah, tes, atau eksperimen dalam dunia engineering yang dapat dirumuskan sebagai masalah pada uji hipotesis [8].

Akan dilakukan uji normalitas terhadap data akurasi estimasi waktu yang diperoleh menggunakan metode Shapiro Wilk.

Tabel 1. Tests of Normality

\begin{tabular}{|l|l|l|l|l|l|l|}
\hline \multirow{2}{*}{} & \multicolumn{3}{|c|}{ Kolmogorov-Smirnov $^{\mathrm{a}}$} & \multicolumn{3}{c|}{ Shapiro-Wilk } \\
\cline { 2 - 7 } & Statistic & df & Sig. & Statistic & df & Sig. \\
\hline Hasil & 0.161 & 30 & 0.047 & 0.931 & 030 & 0.053 \\
\hline
\end{tabular}

Berdasarkan Tabel 1 diperoleh nilai shapiro-wilk sig sebesar 0,053>0,05 sehingga dapat disimpulkan bahwa data akurasi waktu estimasi penyelesaian tugas akhir berdistribusi normal. Dengan demikian asumsi normalitas dalam uji hipotesis mean sample tunggal sudah terpenuhi.

Uji hipotesis mean sampel tunggal untuk analisis optimistic bias pada estimasi penyelesaian tugas akhir yaitu:

Ho: $\mu=0$, menunjukan tidak terdapat bias/kesalahan yang sistematis

$\mathrm{H}_{1}: \mu \neq 0$, menunjukan terdapat bias/kesalahan yang sistematis

$$
\propto=0,05_{\text {two tailed }}
$$

Tabel 2. Uji Hipotesis Mean Sampel Tunggal Akurasi Estimasi Waktu

\begin{tabular}{|l|l|l|l|l|l|}
\hline n & t-hitung & t-tabel & p-value & Kesimpulan & Interpretasi \\
\hline 30 & $-3,38$ & 2.0452 & 0,002 & $\begin{array}{l}\mathrm{H}_{1}: \mu \neq 0 \rightarrow \\
\text { Terdapat bias }\end{array}$ & t-hitung < t-tabel $\rightarrow$ Optimistic Bias \\
\hline
\end{tabular}

Berdasarkan Tabel 2 data akurasi waktu memberikan nilai t-hitung estimasi waktu berada pada rejection area dari t-tabel dan nilai $p$-value $<\propto\left(0,05_{\text {two tailed }}\right)$, sehingga dapat menolak $\mathrm{H}_{0}$. Secara statistik dapat disimpulkan bahwa terdapat kesalahan sistematis / bias pada data akurasi pada estimasi waktu penyelesaian tugas akhir.

Seorang estimator berpengalaman kemungkinan memiliki pemahaman terhadap setiap proses dan hubungannya, namun hal tersebut tidak menjamin bahwa proses nya dilakukan secara rasional, menggunakan tinjauan ilmiah, dan menggunakan informasi yang valid [9]

Akurasi waktu terjadi Optimistic bias karena nilai estimasi tersebut cenderung lebih kecil jika dibandingkan dengan nilai waktu aktualnya. 


\subsection{Uji Beda Akurasi Estimasi Responden}

Analisis selanjutnya adalah analisis uji hipotesis sampel ganda menggunakan uji $\mathrm{t}$ saling bebas karena data sampel berukuran kecil. Uji t dilakukan untuk melihat ada atau tidaknya perbedaan akurasi mahasiswa putra maupun mahasiswa putri saat melakukan estimasi waktu penyelesaian tugas akhir. Uji hipotesis mean sampel ganda adalah pengujian hipotesis dengan menggunakan mean sebagai acuan dan menggunakan dua set data. Salah satu metode uji hipotesis mean sampel ganda adalah uji t-berpasangan untuk dua set data populasi atau sampel yang saling tergantung / dependent [10]. Hipotesis yang digunakan dalam uji t independen yaitu:

Ho: $\mu_{\text {expert }}=\mu_{\text {novice }} \rightarrow$ tidak terdapat perbedaan akurasi antara kedua kelompok data

$\mathrm{H}_{1}: \mu_{\text {expert }} \neq \mu_{\text {novice }} \rightarrow$ ada perbedaan akurasi antara kedua kelompok data $\alpha=0,05_{\text {two }}$ tailed

Tabel 3. Rangkuman Hasil Perhitungan Uji Hipotesis Sampel Ganda Pada Akurasi Estimasi Waktu Penyelesaian Tugas Akhir

\begin{tabular}{|l|l|l|c|l|}
\hline Variabel & t-hitung & t-tabel & Sig. $(\boldsymbol{p}$-value $)$ & Kesimpulan \\
\hline $\begin{array}{l}\text { Putra vs } \\
\text { Putri }\end{array}$ & 0,67 & \pm 2.09 & $0,5>\alpha$ & $\begin{array}{l}\mathbf{H}_{1}: \boldsymbol{\mu}_{\text {expert }} \neq \boldsymbol{\mu}_{\text {novice }} \rightarrow \\
\text { tidak ada perbedaan } \\
\text { antara kedua kelompok } \\
\text { data }\end{array}$ \\
\hline
\end{tabular}

Tabel 4. Rangkuman Hasil Perhitungan Akurasi Estimasi Waktu Penyelesaian Tugas Akhir

\begin{tabular}{|l|l|l|l|l|l|}
\hline Variabel & Responden & $\mathbf{N}$ & $\begin{array}{l}\text { Selisih Rata- } \\
\text { rata }\end{array}$ & Kesimpulan & Interpretasi \\
\hline \multirow{2}{*}{ Waktu } & Mhs. Putra & 17 & $-2,11$ & \multirow{2}{|}{$\left|\boldsymbol{\mu}_{\text {waktu putra }}\right|$} & $\begin{array}{l}\text { Estimasi } \\
\text { waktu putri } \\
\text { lebih akurat } \\
\text { dari putra }\end{array}$ \\
\cline { 2 - 4 } & Mhs. Putri & 13 & $-1,38$ & $\boldsymbol{\mu}_{\text {waktu putri }} \mid$ \\
\hline
\end{tabular}

Berdasarkan Hasil perhitungan Tabel 3, nilai t-hitung pada variabel akurasi waktu dan akurasi biaya berada pada rejection area dan nilai sig. $(p$-value) $>\propto$, sehingga menerima $\mathrm{H}_{0}$. Secara statistik dapat disimpulkan bahwa tidak terdapat perbedaan data akurasi estimasi penyelesaian tugas akhir antara mahasiswa putra dan putri.

Berdasarkan Tabel 4, pada kolom kesimpulan tanda mutlak menunjukan jarak mean selisih terhadap nilai 0 . Nilai mean selisih waktu dari kelompok mahasiswa putri lebih rendah dari kelompok mahasiswa putra. Sehingga dapat dinyatakan estimasi waktu proyek kelompok mahasiswa putri lebih akurat dari kelompok mahasiswa putra.

\section{Kesimpulan}

Berdasarkan Analisa dan pembahasan maka dapat diambil kesimpulan terdapat kesalahan sistematis / bias pada data akurasi pada estimasi waktu penyelesaian tugas akhir. Akurasi waktu terjadi Optimistic bias karena nilai estimasi tersebut cenderung lebih kecil jika dibandingkan dengan nilai waktu aktualnya. Secara statistik dapat disimpulkan bahwa tidak terdapat perbedaan data akurasi estimasi penyelesaian tugas akhir antara mahasiswa putra dan putri. Estimasi waktu proyek kelompok mahasiswa putri lebih akurat dari kelompok mahasiswa putra. 


\section{Ucapan Terimakasih}

Terimakasih kepada seluruh pihak yang telah membantu kelancaran dan keberhasilan untuk penyelesaian penelitian ini.

\section{Daftar Pustaka}

[1] Constantianus, F., \& Suteja, B. R. (2005). Analisa dan Desain Sistem Bimbingan Tugas Akhir Berbasis Web dengan Studi Kasus Fakultas Teknologi Informasi. Jurnal Teknik Informatika dan Sistem Informasi, 1(2).

[2] Machmud, M. (2016). Tuntunan Penulisan Tugas Akhir Berdasarkan Prnsip Dasar Penelitian Ilmiah. Research Report.

[3] Sharot, T. (2011). The optimism bias. Current biology, 21(23), R941-R945.

[4] PMI, A. (2013). guide to the project management body of knowledge (PMBOK guide). In Project Management Institute (Vol. 5).

[5] Youker, R. (2013). The Difference Between Different Types of Projects, Project Perspective, Vol. 35, 12-15.

[6] Hastie, R., \& Dawes, R. M. (2010). Rational choice in an uncertain world: The psychology of judgment and decision making. Sage.

[7] Tversky, A., \& Kahneman, D. (1974). Judgment under uncertainty: Heuristics and biases. science, 185(4157), 1124-1131.

[8] Montgomery, D. C., \& Runger, G. C. (2007). Applied statistics and probability for engineers, (With CD). John Wiley \& Sons.

[9] Cleaves, D. A. (1994). Assessing uncertainty in expert judgments about natural resources. Gen. Tech. Rep. SO-110. New Orleans, LA: US Dept of Agriculture, Forest Service, Southern Forest Experiment Station. 17 p., 110.

[10] Blank, L. (1980). Statistical procedures for engineering, management, and science. McGraw-Hill,Inc. 
Bagus Wahyu Utomo

E-480 